\title{
Screening of Acetic Acid Producing Microorganisms from Decomposed Fruits for Vinegar Production
}

\author{
Farzana Diba1, Fahmida Alam ${ }^{1,2}$, Ali Azam Talukder1* \\ ${ }^{1}$ Department of Microbiology, Jahangirnagar University, Dhaka, Bangladesh \\ ${ }^{2}$ Human Genome Centre, School of Medical Sciences, Universiti Sains Malaysia, Kubang Kerian, Malaysia \\ Email: aat@juniv.edu, tunubj@yahoo.com
}

Received 11 February 2015; accepted 5 May 2015; published 7 May 2015

Copyright (C) 2015 by authors and Scientific Research Publishing Inc.

This work is licensed under the Creative Commons Attribution International License (CC BY). http://creativecommons.org/licenses/by/4.0/

c) (i) Open Access

\begin{abstract}
Acetic acid bacteria capable of growing at $30^{\circ} \mathrm{C}-37^{\circ} \mathrm{C}$ were collected from various decomposed fruits available in Bangladeshi local markets in order to assess their suitability for vinegar production. Initially, 42 microorganisms were isolated from decomposed fruits like grapes, mangoes, pineapples, oranges, safeda etc. during summer when temperature reaches up to $37^{\circ} \mathrm{C}$. Then their growths were checked in YPG medium containing various ethanol concentrations at different time point at $37^{\circ} \mathrm{C}$. From the preliminary screening, $15 \mathrm{Gram}$ negative bacterial isolates have produced halos or yellow zone around the colonies on YPG agar plate at $37^{\circ} \mathrm{C}$ which indicated acetic acid production capability by those bacteria. Furthermore, acetic acid production rates were determined by titration method and about $3-6.9 \mathrm{gm} / 100 \mathrm{ml}$ acetic acid were estimated by using $4 \%$ ethanol at $37^{\circ} \mathrm{C}$ by shaking culture for 3 days. Several biochemical analysis revealed that our collection contained huge amount of acetic acid producing bacteria and some of them could be potential candidates for vinegar production.
\end{abstract}

\section{Keywords}

Decomposed Fruit, High Temperature, Fermentation, Acetic Acid, Vinegar

\section{Introduction}

Vinegar is a precious food additive and complement as well as effective preservative against food spoilage. According to FDA (Food and Drug Administration of the United States), vinegar contains 4\% acetic acid that is produced from sugary materials through alcoholic fermentation [1]-[3]. Acetic acid is the predominant flavoring

\footnotetext{
${ }^{*}$ Corresponding author.
}

How to cite this paper: Diba, F., Alam, F. and Talukder, A.A. (2015) Screening of Acetic Acid Producing Microorganisms from Decomposed Fruits for Vinegar Production. Advances in Microbiology, 5, 291-297. 
and antimicrobial component in vinegar. Vinegar industry produces several types of vinegar by various qualified native or engineered acetic acid bacteria recently [2]-[4]. Vinegar production was carried out by biological oxidation of ethanol using acetic acid bacteria. This process is a two-step reaction involving two membrane-bound enzymes, alcohol dehyhrogenase (ADH) and aldehyde dehydrogenase (ALDH). Cytochrome-c and terminal oxidase are also involved in ethanol oxidation [5].

Acetic acid bacteria are obligate aerobic Gram negative bacteria. They are able to oxidize ethanol to acetic acid. On the basis of their abilities to over oxidize acetate or lactate and the positions of their flagella, these bacteria were categorized into two genera-Acetobacter and Gluconobacter [6] [7]. Acetobacter oxidize ethanol more efficiently than glucose. On the other hand Gluconobacter utilize glucose more than ethanol. Acetobacter is the most useful strains in vinegar production than Gluconobacter which is used for industrial purposes such as fermentation of ketogluconic acid, sorbose and dihydroxyacetone [8].

Recently, in summer season the temperature has gradually increased in most countries of the world. For this reason vinegar can be produced for only half the year by most of the domestic vinegar manufacturers. Nowadays, various technologies such as recombinant DNA technology and genetically modified cells have been established to improve the quality of industrial bacterial properties to increase the rate of acetic acid production or to enhance the tolerance to high acetic acid, ethanol and fermentation temperature [9] [10]. The interest of vinegar production using acetic acid bacteria may also economically profitable [11]. For oxidative fermentation, huge development in isolation, identification and characterization of this group of bacteria were found [12] [13]. In this study, we intended to isolate acetic acid bacteria from the natural sources (decomposed fruits) of Bangladesh to assess their potentiality for vinegar production.

\section{Materials and Methods}

\subsection{Sample Collection}

For isolation of acetic acid producing microorganisms, different rotten fruits (grapes, mangoes, oranges, pineapples, safeda etc.) were collected from various local places in Dhaka, Bangladesh during summer. Three percent acetic acid and $4 \%$ ethanol were prepared in several sterile plastic bottles. Some pieces of rotten fruits were submerged in 3\% acetic acid and $4 \%$ ethanol solution in different bottles and incubated at $37^{\circ} \mathrm{C}$ for 7 - 8 days. After incubation, microbial growths were observed in the solutions. For inhibiting bottle's explosion due to alcoholic fermentation, a few tiny punctures were made on the top of the bottles for extra gas exchange.

\subsection{Media Preparation and Isolation of Acetic Acid Bacteria}

Yeast Extract, Polypeptone and Glycerol (YPG) media was prepared containing bromocresol purple (100 mg/ml) as indicator with either $4 \%$ acetic acid or $5 \%$ ethanol. This selective media normally shows halos or yellow color around organism's colony if the organism is capable of producing acetic acid. $75 \mu \mathrm{l}$ of suspension from each of $3 \%$ acetic acid and $4 \%$ ethanol containing bottles was taken and performed spreading on YPG media. Incubation was done at $37^{\circ} \mathrm{C}$ and growth was observed after 24 hour. Several yellowish, light bluish colonies were observed on YPG plates from different samples. Colonies were subcultured in YPG solid and liquid medium for further analysis. Suspected acetic acid bacterial isolates from YPG medium were inoculated onto nutrient agar plates and were further identified by morphological characters of colonies (shape, size, edge, elevation, form and opacity) developed after 18 - 24 hour of incubation. Gram staining and some biochemical tests such as Kigler Iron Agar (KIA) test, Indole test, Catalase test, Oxidase test, Nitrate reduction test and Motility test were performed.

\subsection{Estimation of Acetic Acid Production Rate}

Cells were incubated at various time points in liquid Carr medium containing different concentrations of ethanol and acetic acid production rate was estimated by titration method as described earlier by Beheshti and Shafiei [14]. In brief, $5 \mathrm{ml}$ of the liquid medium with cultured microbial cells was added to $20 \mathrm{ml}$ of distilled water in a $250 \mathrm{ml}$ flask and mixed thoroughly with 5 drops of phenolphthalein used as $\mathrm{pH}$ indicator [phenolphthalein, $0.1 \mathrm{~g}$; ethanol, $60 \mathrm{~g}$; distilled water, $40 \mathrm{~g}$ ] and then 0.5 normal sodium hydroxide $(\mathrm{NaOH})$ was added using $200 \mathrm{ml}$ burette and mixed until pale pink color appeared in the flask. The volume of consumed $\mathrm{NaOH}$ was measured from the burette and the acetic acid percentage of each liquid medium with particular isolates was computed. The to- 
tal amount of (in gm) of acetic acid produced in $100 \mathrm{ml}$ of medium was calculated using the following formula: Acetic acid $(\mathrm{g} / 100 \mathrm{ml})=$ Volume of $\mathrm{NaOH}(\mathrm{ml})$ used in titration $\times 0.03 \times 20$.

\section{Results and Discussion}

The aim of this study was to isolate acetic acid producing microorganisms from the various natural sources of Bangladesh. For this reason, we targeted various decomposed fruit samples. A total of 42 (white, brown and yellow pale colored) colonies on YPG agar plates were derived from rotten fruit samples collected from various fruit markets of Bangladesh (Figure 1). Out of 42 isolated colonies, 15 suspected acetic acid bacteria were screened on the basis of their morphological and cultural properties (Figure 2). A reference strain, 3283R of acetic acid bacteria was gifted by Dr. K Matsushita, Yamaguchi University, Japan which was used as an internal control for all the experiments.

\subsection{Morphological Characterization}

Fifteen strains were primarily screened and detected as acetic acid bacteria because they produced halos or yellow color around their colonies in the selective YPG culture medium (Figure 2). Examination using Gram staining revealed that all the isolates were Gram negative and microscopic observation of the strains showed rod,

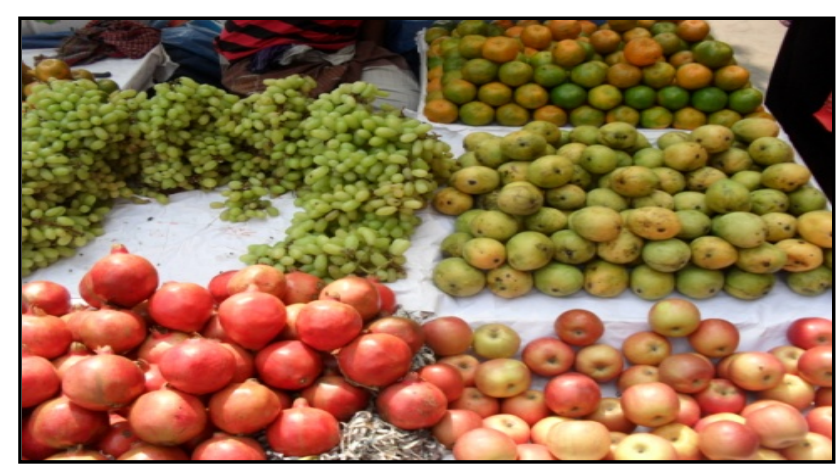

(a)

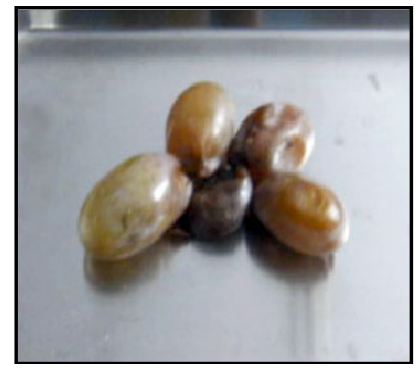

(b)

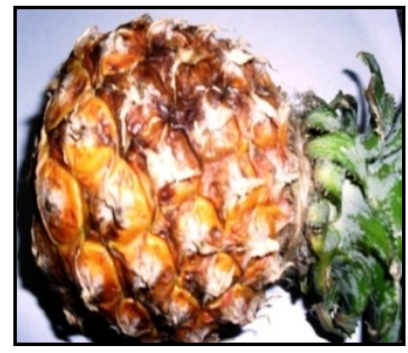

(d)

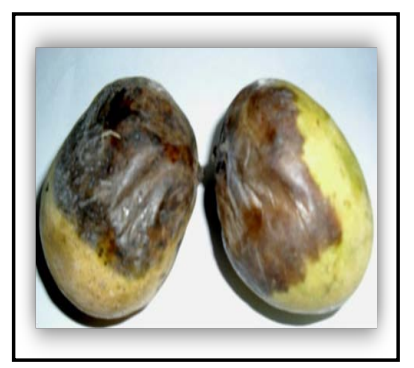

(c)

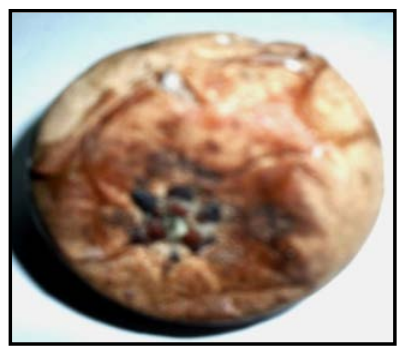

(e)

Figure 1. Various decomposed fruit samples were collected for isolating acetic acid bacteria for vinegar production. Here, (a) Fresh fruits used as a source of internal control, whereas (b)-(e), represent the sources of experimental samples (b) Mango; (c) Grapes; (d) Pineapple; (e) Safeda collected from the fruit markets of Dhaka, the capital of Bangladesh. 
small round shape or arranged in chain (Figure 3). Both motile and non motile bacteria were found.

\subsection{Biochemical Characterization}

Various biochemical tests such as Kligler's Iron Agar (KIA) test, Oxidase test, Catalase test, Motility test and Nitrate reduction test were performed using the selected 15 Gram negative bacterial isolates according to the standard guideline of Bergey's manual of determinative bacteriology [15]. Results of these tests are listed in Table 1. Several biochemical characterizations indicated that our isolates are acetic acid bacteria as suggested previously by Gullo et al. [16] and Beheshti et al. [14]. Acetic acid bacteria are characterized by the ability to oxidize alcohols or sugars incompletely and a common feature to most of them is the ability to oxidize ethanol to acetic acid. Acid production from ethanol, generally shown (Figure 4) with the method described by Nanda [17] as a clearing of the opacity in the medium around the bacterial growth or with the method described by Carr as a color change of the bromocresol purple indicator in the medium from purple to yellow. This confirmed the findings in the present study that the bacterial isolates may be Acetobacter [18].

\subsection{Estimation of Acetic Acid Production Rate}

Morphologically identified and biochemically confirmed acetic acid bacterial isolates were then further checked for their abilities to produce acetic acid by titration in YGEA (Yeast, Glucose, Ethanol, Acetic acid) medium. Acetic acid production rate varied among the isolates at different incubation time periods. Among 15 acetic acid producing strain, F-10 showed the highest acetic acid production $(6.9 \mathrm{~g} / 100 \mathrm{ml})$ rate at $37^{\circ} \mathrm{C}$ that was much higher than the reference strain 3283R which produced $3.9 \mathrm{~g} / 100 \mathrm{ml}$ and F-5 showed the lowest production (3.18 $\mathrm{g} / 100 \mathrm{ml}$ ) at $4 \%$ ethanol concentration (Figure 5).

In this study, we could not perform group identification (either Acetobacter or Gluconobacter) of our isolated strains. So for their group identification, further study have to be carried out based on their DNA sequences, thermostability of ADH and ALDH, effects of initial acetic acid concentrations on vinegar fermentation, continuous vinegar fermentation at higher temperatures and vinegar fermentation at static culture.
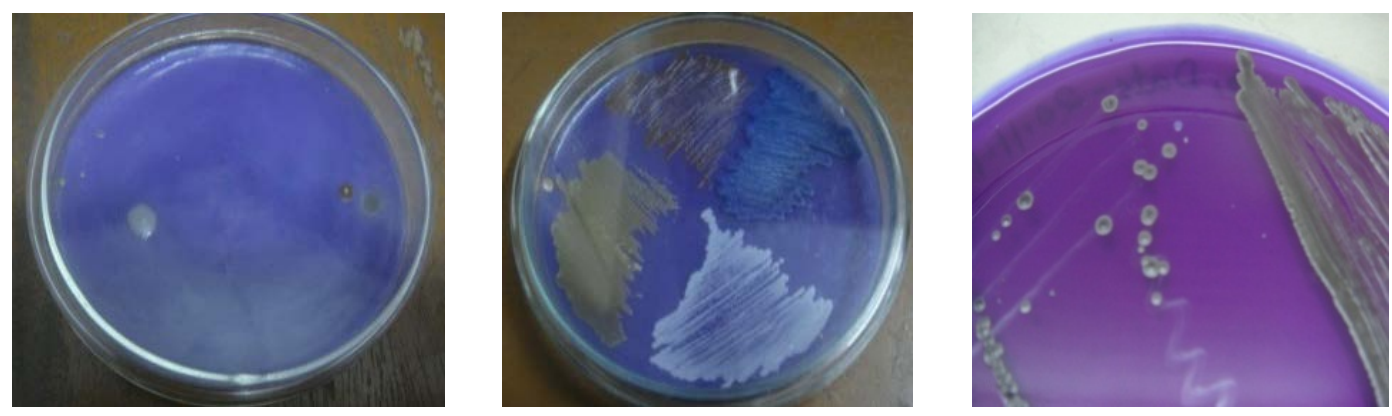

Figure 2. Screening of acetic acid producing microorganisms on YPG solid plates containing 4\% ethanol. Sample collection and screening procedures are explained in detail in Materials and Methods. Clear halos around the colonies were seen (left), which indicated acetic acid production capability of acetic acid producing bacteria.

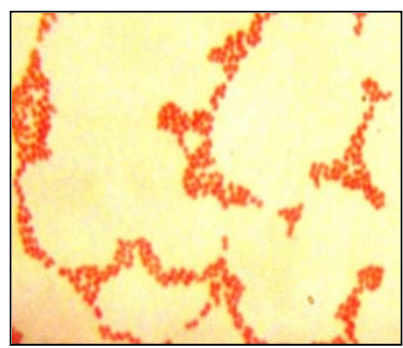

(a)

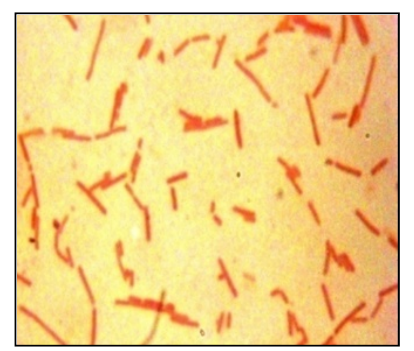

(b)

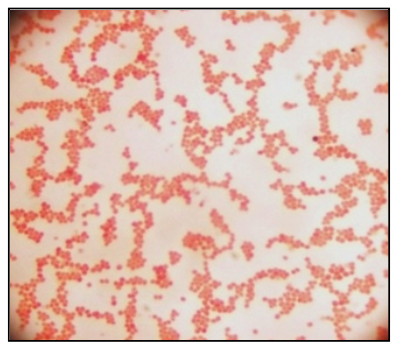

(c)

Figure 3. Microscopic observation of acetic acid producing positive isolates. Sample collection, cell culture, Gram staining and preparation for microscopic observation were explained in Materials and Methods. Here, (a) (b) and (c) represent isolate F-06, F-10 and reference strain (3283R), respectively. 


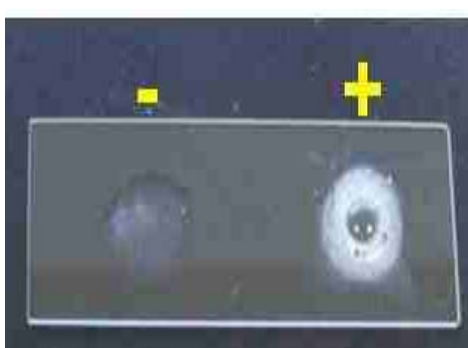

(a)

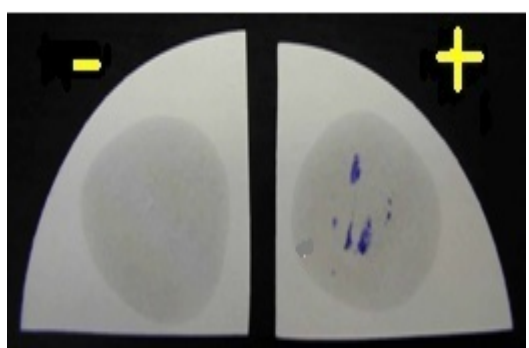

(b)
Indole (-) Indole (+) AAPB

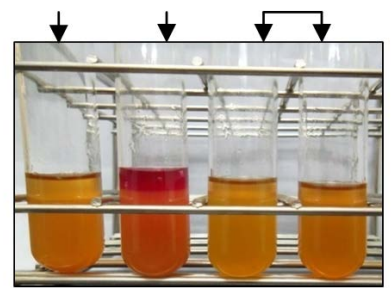

(c)

Figure 4. Biochemical characterization of some acetic acid producing bacteria. Here, right, middle and left panels represent the results of Catalase (F-01), Oxidase (F-03) and Indole test (F-01), respectively. AAPB = Acetic acid positive bacteria. (a) Catalase test; (b) Oxidase test; (c) Indole test.

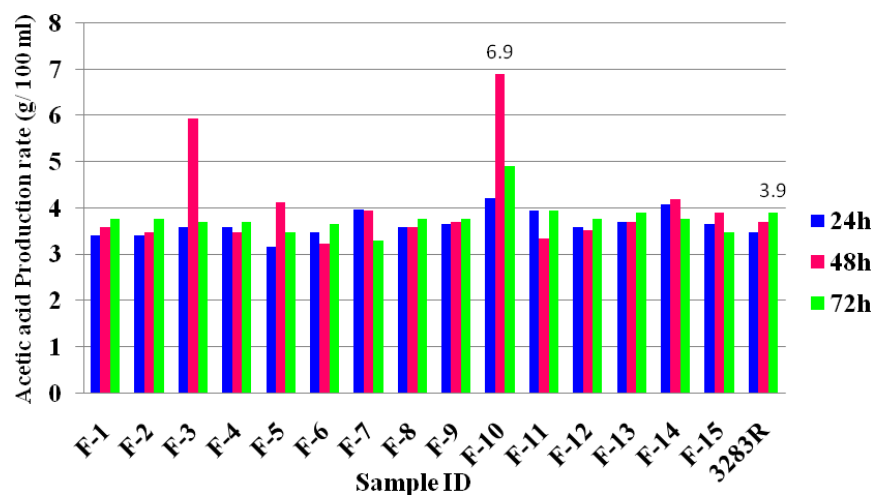

Figure 5. Effect of $4 \%$ ethanol concentration on acetic acid production. Sample collection, cell culture and cell preparation for acetic acid estimation by titration method was explained in Materials and Methods. Here, F-10 showed the highest acetic acid production $(6.9 \mathrm{~g} / 100 \mathrm{ml})$ rate at $37^{\circ} \mathrm{C}$, much higher than the reference strain $3283 \mathrm{R}$ which produced acetic acid 3.9 $\mathrm{g} / 100 \mathrm{ml}$ after 72 hours of incubation.

Table 1. Summary of biochemical test results of acetic acid producing bacteria.

\begin{tabular}{|c|c|c|c|c|c|c|c|}
\hline \multirow{2}{*}{ Sample ID } & \multicolumn{7}{|c|}{ Biochemical Test } \\
\hline & Catalase & Oxidase & Indole & $\mathrm{H}_{2} \mathrm{~S}$ gas production & Motility & $\mathrm{NO}_{3}^{-}$ & Reduction \\
\hline F 01 & +++ & - & - & - & - & & - \\
\hline F 02 & +++ & - & - & - & + & & + \\
\hline F 03 & + & - & - & - & + & & + \\
\hline F 04 & ++ & - & - & - & - & & - \\
\hline F 05 & ++ & - & - & - & + & & + \\
\hline F 06 & + & - & - & - & - & & + \\
\hline F 07 & + & - & - & - & - & & - \\
\hline F 08 & +++ & - & - & - & + & & + \\
\hline F 09 & ++ & - & - & - & - & & - \\
\hline F 10 & +++ & - & - & - & + & & - \\
\hline F 11 & +++ & - & - & - & + & & - \\
\hline F 12 & ++ & - & - & - & + & & - \\
\hline F 13 & ++ & - & - & - & + & & - \\
\hline F 14 & +++ & - & - & - & + & & - \\
\hline F 15 & +++ & - & - & - & + & & - \\
\hline 3283R (Reference strain) & +++ & - & - & - & - & & + \\
\hline
\end{tabular}

Here, $+++=$ Strongly positive; $++=$ Moderately positive; $+=$ Positive and - = Negative. 


\section{Conclusion}

We have successfully isolated and screened 15 Gram negative bacterial acetic acid producing bacteria from the various decomposed fruits available in Bangladesh. These bacteria could grow well at $37^{\circ} \mathrm{C}$ and capable of producing maximum acetic acid under the conditions we employed. Among them some acetic acid producing bacteria would be potential candidates for vinegar production at higher temperatures because high temperature fermentation employing acetic acid producing bacteria may reduce expenses of cooling water and reduce the risk of contamination. Nowadays, acetic acid is an important industrial organic chemical with approximately millions of tons/year being produced and consumed worldwide. Therefore, acetic acid production rate is optimized under various physiological conditions by microbial methods.

\section{Acknowledgements}

This research was financially supported the Ministry of Education (17/10, M-15/2007/226), Bangladesh. We thank Professor Dr. K Matsushita, Yamaguchi University, Japan for gift of acetic acid producing reference strain, 3283R.

\section{References}

[1] Joyeux, A., Lafon-Lafourcade, S. and Ribéreau-Gayon, P. (1984) Evolution of Acetic Acid Bacteria during Fermentation and Storage of Wine. Applied and Environmental Microbiology, 48, 153-156.

[2] Drysdale, G. and Fleet, G. (1985) Acetic Acid Bacteria in Some Australian Wines. 17-20.

[3] Kocher, G., Kalra, K. and Phutela, R. (2006) Comparative Production of Sugarcane Vinegar by Different Immobilization Techniques. Journal of the Institute of Brewing, 112, 264-266. http://dx.doi.org/10.1002/j.2050-0416.2006.tb00722.x

[4] Harada, T. and Mori, H. (1971) Mutants of Acetic Acid Bacteria Used in Vinegar Production. Journal of Fermentation Technology, 49, 836-841.

[5] Tamaki, T., Fukaya, M., Takemura, H., Tayama, K., Okumura, H., Kawamura, Y., Nishiyama, M., Horinouchi, S. and Beppu, T. (1991) Cloning and Sequencing of the Gene Cluster Encoding Two Subunits of Membrane-Bound Alcohol Dehydrogenase from Acetobacter polyoxogenes. Biochimica et Biophysica Acta, 1088, 292-300. http://dx.doi.org/10.1016/0167-4781(91)90066-U

[6] De Ley, J., Gillis, M. and Swings, J. (1984) Family VI. Acetobacteriaceae, Bergey’s Manual of Systematic Bacteriology. In: Krieg and Holt, J.G., Eds., The Williams and Wilkin Co., Baltimore, Vol. 1, 267-278.

[7] Yamada, Y., Okada, Y. and Kondo, K. (1976) Isolation and Characterization of "Polarly Flagellated Intermediate Strains” in Acetic Acid Bacteria. The Journal of General and Applied Microbiology, 22, 237-245. http://dx.doi.org/10.2323/jgam.22.237

[8] Swings, J. (1991) The Genera Acetobacter and Gluconobacter. Springer, New York, 2268-2286.

[9] Lotong, N., Malapan, W., Boongorsrang, A. and Yongmanitchai, W. (1989) Production of Vinegar by Acetobacter Cells Fixed on a Rotating Disc Reactor. Applied Microbiology and Biotechnology, 32, 27-31. http://dx.doi.org/10.1007/BF00164818

[10] Fukaya, M. (1994) Vinegar: Genetic Improvement of Acetobacter and Gluconobacter. Marcel Dekker, New York, Basel, Hong Kong, 529-542.

[11] Saeki, A., Taniguchi, M., Matsushita, K., Toyama, H., Theeragool, G., Lotong, N. and Adachi, O. (1997) Microbiological Aspects of Acetate Oxidation by Acetic Acid Bacteria, Unfavorable Phenomena in Vinegar Fermentation. Bioscience Biotechnology and Biochemistry, 61, 317-323. http://dx.doi.org/10.1271/bbb.61.317

[12] Saeki, A., Theeragool, G., Matsushita, K., Toyama, H., Lotong, N. and Adachi, O. (1998) Development of Thermotolerant Acetic Acid Bacteria Useful for Vinegar Fermentation at Higher Temperatures. Bioscience Biotechnology and Biochemistry, 61, 138-145. http://dx.doi.org/10.1271/bbb.61.138

[13] Adachi, O., Moonmangmee, D., Toyama, H., Yamada, M., Shinagawa, E. and Matsushita, K. (2003) New Developments in Oxidative Fermentation. Applied Microbiology and Biotechnology, 60, 643-653. http://dx.doi.org/10.1007/s00253-002-1155-9

[14] Beheshti Maal, K. and Shafiei, R. (2010) Isolation and Characterization of an Acetobacter Strain from Iranian White-Red Cherry as a Potential Strain for Cherry Vinegar Production in Microbial Biotechnology. Asian Journal of Biotechnology, 2, 53-59. http://dx.doi.org/10.3923/ajbkr.2010.53.59

[15] Goodfellow, M., Peter, K., Busse, H., Trujillo, M.E., Ludwig, W., Suzuki, K.-I. and Parte, A. (2012) Bergey’s Manual 
of Systematic Bacteriology. Volume 5, The Actinobacteria, Springer, New York.

[16] Gullo, M., Caggia, C., De Vero, L. and Giudici, P. (2006) Characterization of Acetic Acid Bacteria in "Traditional Balsamic Vinegar”. International Journal of Food Microbiology, 106, 209-212. http://dx.doi.org/10.1016/j.ijfoodmicro.2005.06.024

[17] Nanda, K., Taniguchi, M., Ujike, S., Ishihara, N., Mori, H., Ono, H. and Murooka, Y. (2001) Characterization of Acetic Acid Bacteria in Traditional Acetic Acid Fermentation of Rice Vinegar (Komesu) and Unpolished Rice Vinegar (Kurosu) Produced in Japan. Applied and Environmental Microbiology, 67, 986-990. http://dx.doi.org/10.1128/AEM.67.2.986-990.2001

[18] Ilha, E.C., Sant'Anna, E., Torres, R.C., Porto, A.C. and Meinert, E.M. (1999) Utilization of Bee (Apis mellifera) Honey for Vinegar Production at Laboratory Scale. Acta Cientifica Venezolana, 51, 231-235. 